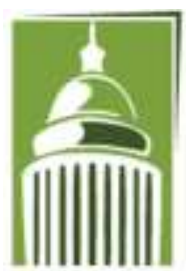

ARF
Global Proceedings Repository

American Research Foundation

ISSN 2476-017X

Available online at http://proceedings.sriweb.org

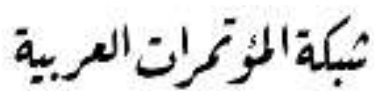

http://arab.kmshare.net/

The 10th International Scientific Conference

Under the Title

"Geophysical, Social, Human and Natural Challenges in a Changing Environment"

$$
\begin{aligned}
& \text { المؤتمر العلمي الدولي العاشر } \\
& \text { تحت عنوان "التحديات الجيوفيزيائية والاجتماعية والانسانية والطبيعية في بيئة متغيرة" } \\
& \text { - اسطنبول - تركيا2019 يوليو - تموز } 25 \text { - } 26
\end{aligned}
$$

http://kmshare.net/isac2019/

\title{
Investigation for Pectinase Pathogenicity \& Activity of Mycological disease (Leaf Spot) in Solanum lycopersicum
}

\author{
Intesar Ali Mezeal and Maayad Salh Hussin \\ Department of Biology, College of Sciences, Mustansiriyah University, Iraq . \\ E.mail:intesarali664@uomustansiriyah.edu.iq
}

\begin{abstract}
Pathogenic ability of many fungal species qualified for nine of genera were recognized. (8) fungi were optimistic and positively talented to contaminate leaves of tomato seeming contamination indicators for the disease ( leaf spot). Alternaria citri Alternaria alternata, Alternaria tenuissima , Botrytis cinerea, Botrytis squamosa were extremely infectious and formed this desease in most of infested leaves. Consequences protest this, in unhealthy plant life by Alternaria citri the chlorophyll was tremendously communicable presented maximum ominously condensed in $(1.16-0.18)(\mathrm{mg} / \mathrm{g}$ fresh leaves ) for chlorophyll( $\mathrm{a}, \mathrm{b})$ individually associated in $(2-1.50)(\mathrm{mg} / \mathrm{g}$ fresh leaves ) in controller plants. Alternaria alternate also march exciting condensed for chlorophyll (a, b ) were ( $1.89-0.98)(\mathrm{mg} / \mathrm{g}$ fresh leaves ) correspondingly. (6) species were divided to capabilities to products pectinase by (cup-plate) technique. Totally mycological verified remained (pectinase ) inventors then through adaptable shades. (3 )species displayed in height pectinase inactivity include(Alternaria citri, Alternaria tenuissima and Alternaria alternaria) were (29,26 and $23 \mathrm{~mm}$ ) correspondingly, further species were create to be practical pectinase action include(Mycosphaerella tassiana, Botrytis squamosal , Botrytis cinerea). Pectinase formed by Alternaria citri increased by increasing of incubation
\end{abstract}




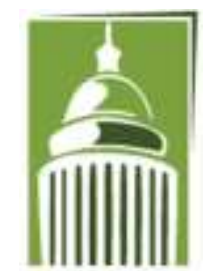

ARF
Global Proceedings Repository

American Research Foundation

ISSN 2476-017X

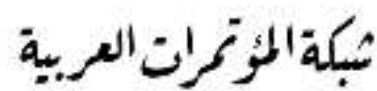

http://arab.kmshare.net/

Available online at http://proceedings.sriweb.org

dated exhibition its supreme afterwards (ten days ) of incubation, in $\left(30^{\circ} \mathrm{C}, \mathrm{pH}=6\right)$. Among numerous carbon cradles shared definitely in the media , (pectin) shaped resolute pectinase structure through Alternaria citri, whereas (peptone )was greatest nitrogen foundation considerable measures to pectinase .

Key words : Tomato, pathogenicity ,Pectinase, Alternaria citri, Leaf Spot.

\section{2-Introduction}

Tomato (Solanum lycopersicum L.) is unique of utmost authoritative vegetable harvests established universal (1). It is cultivated essentially in wholly nations both in arenas and endangered nations( 2). tomato Leaf spot produced by some fungal strains is unique from communal effects reduction tomato's manufacture(3). Over and done with previous inadequate centuries tomato infections has been fashionable nearly each year, essentially owing to soil-borne survival of mold, native over wintering or over summering of inoculum, farming of susceptible varieties and talented environmental locations. Fungiform herbal pathogenic include collection of fungi exhibition definite countless adaptableness throughout their contamination successions. This flexibility agreements for pollute varied diversity from yields (4,5) . service miscellaneous methods for contaminate in addition to inhabit plant life, similarly create multilayered statement stuck in the middle of fungal types plus armies $(6,7,8)$. A diverse break is between conceivable crop and harvest understood at agriculturalist's arena, that were mostly since to number of (biotic \& abiotic ) strains from tomato's harvest was defenseless. The disease leaf spot produced by way of A. solani, was unique in greatest communal, harmful tomato's diseases of yield. plug in leaves, abrasion stem besides produce spots were the greatest harmless indications by disease then crop sufferers $80 \%$ harm via Alternaria species $(9,10,11,12)$. Many houseplant pathogenic elements include bacterial or fungal strains has protracted remained documented for products pectin lytic enzyme, widely recognized production in the enzyme was a chief resources through this microbe inhabit tissue crowd (13). Contribution in pectin enzyme fashionable squalor from pectin supporters in cell wall besides the middle lamella in herb tissue were designated to varied kinds from infections like (blights, soft rot, wilts, dry rot and leaf spots $)(14)$. 


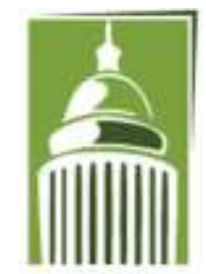

ARF
Global Proceedings Repository

American Research Foundation

ISSN 2476-017X

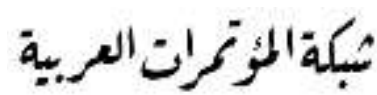

http://arab.kmshare.net/

Available online at http://proceedings.sriweb.org

\section{3-Supplies \& Procedures}

\section{3-1Assortment of Tomato samples}

(40) diseased leaves examples of Tomato were composed as of dissimilar cultured areas in (Baghdad - Iraq). All taster placed in a sterilized polyethylene carrier bag and transported to fungi . Tasters reserved at $\left(4^{\circ} \mathrm{C}\right)$ up until mycological examination.

\section{3-2isolation fungi from leaf superficial}

Leaf superficial fungal species from Tomato's plant were insulated of unhealthy plant leaves conferring towards procedures designated in (15) proceeding PDA.

\section{3-3Pathogenicity test}

(15) species of fungi composed as of unhealthy Tomato leaves were appraised for pathogenicity of Tomato (16).Tomato were full-grown in a greenhouse through experimentation. Pathogenicity assessment was approved out by disinfected soil placed in $(20 \mathrm{~cm})$ pot. Seeds superficial sanitized through from mercuric chloride $(0.1) \%$. washed numerous times by sanitized seawater. (10 ) tomato's seed spread fashionable every pots. Spores suspension of designated fungi secondhand for injection in plant (20) $\mathrm{mL} /$ plant covering (106) cfu/mL . all fungal species cultured in PDA. Pathogenic symptoms of designated fungi were examined after (45) days via leaves scattering, these grownup fashionable greenhouse to (15) days. (3) from replicates that secondhand to every verified isolates, plants were scattered through sanitized distilled water used as control .

\section{3-4Photosynthetic pigments extraction}

chlorophyll a ,chlorophyll b resolute by (spectrophotometric technique). This pigments removed by recognized heaviness renewed leaves at (85)\% aqueous acetone. Excerpt centrifuged at $7000(\mathrm{rpm})$ to $15(\mathrm{~min})$, supernatant 


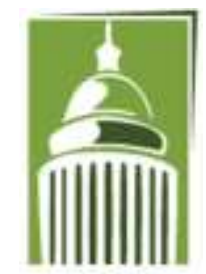

AR F
Global Proceedings Repository

American Research Foundation

ISSN 2476-017X

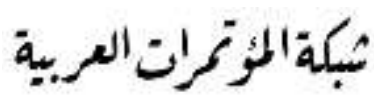

http://arab.kmshare.net/

Available online at http://proceedings.sriweb.org

poured, finished toward certain capacity with aqueous acetone (85)\% to convert appropriate to spectrophotometric dimensions. Absorption of pigment segments Chlorophyll a, Chlorophyll b unhurried to (663)and (648) $\mathrm{nm}$ ( 17).

\section{3-5Transmission fungal species designed for manufacture of pectinase:}

(6) types of fungi partitioned to capabilities for products pectinase . Fungi cultivated on (PDA), protected to $28{ }^{\circ} \mathrm{C}$ to fife days .By sterilized plug bit (10 ) $\mathrm{mm}$ disk censored to immunize (50) $\mathrm{ml}$ disinfected liquefied medium (18). Afterwards (7) days of, cultures filtered, filtrates secondhand to perceive activity of pectinase (19), (0.1) $\mathrm{ml}$ filtrate of culture were pipetted in (10) mm hollows completed in plates comprising solid medium. Afterward (1) day of cultivation in $(28)^{\circ} \mathrm{C}$, plates swamped by iodine. Clear zone around the holes designated pectinase activity .

\section{3-6Influences affecting pectinase creation}

A. citri were initiate greatest pectinase creators., working to education influence of dissimilar environmental and nutritious influences on pectinase manufacture .

\section{3-6-1incubation times}

Containers comprising by using Hankin medium $(50 \mathrm{ml}) \mathrm{pH}=5$, immunized by $A$. citri, hatched in $(28)^{\circ} \mathrm{C}$ to $(5,7,10,14)$ days. 3 duplicates secondhand for every treatment. Centrifuged the filtrates to (15) min. to (15000 )rpm sure supernatants assessed to pectinase (20).

\section{3-6-2Temperature}

(50) $\mathrm{ml}$ of liquefied medium injected by ( A. citri), protected to ( 20, 25, 30, $35){ }^{\circ} \mathrm{C}$ to $(7$ )days. 3 duplicates were prepared to every management. At the finale of cultivation time, cultures filtered, centrifuged to (15) min. to (15000 ) rpm, pure supernatants were assessed to activity of pectinase. 


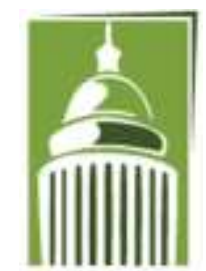

ARF
Global Proceedings Repository

American Research Foundation

ISSN 2476-017X

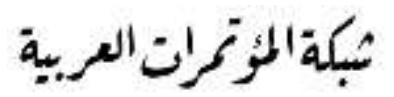

http://arab.kmshare.net/

Available online at http://proceedings.sriweb.org

\section{3-6-3pH values}

Containers covering (50) $\mathrm{ml}$ from medium attuned to dissimilar $\mathrm{pH}$ values ( $2,4,6,8)$,inoculated with (A.citri). in $(28){ }^{\circ} \mathrm{C}$ to (7 )days. 3 duplicates were prepared to every management. At the finale of cultivation time, cultures filtered, centrifuged to (15) min. to (15000) rpm, pure supernatants were assessed to activity of pectinase.

\section{3-6-4Carbon sources}

Culture media complemented by $0.5 \%$ from (glucose. pectin, CMC, , maltose). immunized by way of A.citri . in (28) ${ }^{\circ} \mathrm{C}$ to (7)days. 3 duplicates were prepared to every management. At the finale of cultivation time, cultures filtered, centrifuged to (15) min. to (15000) rpm, pure supernatants were assessed to activity of pectinase.

\section{3-6-5Nitrogen sources:}

Medium was complemented by using (peptone, ammonium nitrate, sodium nitrite ,potassium nitrate ) in $0.2 \%$, in adding using ammonium sulphate as per controller, in $(28){ }^{\circ} \mathrm{C}$ to $(7$ )days. 3 duplicates were prepared to every management. At the finale of cultivation time, cultures filtered, centrifuged to (15) min. to (15000) rpm, pure supernatants were assessed to activity of pectinase .

\section{4-Consequences \& Conversation}

\section{4-1Isolated fungi}

Fungal growing occurred on all revealing leaves, Initially (15) mycological species remained supposed that include (Curvularia lunata, Stachybotrys chartarum, Mycosphaerella tassiana, Cladosporium cladosporioides, Cladosporium sphaerspermum, Drechslera papendorfii Fusarium oxysporum, Fusarium moniliforme,Fusarium solani, Alternaria tenuissima, Alternaria alternate, Alternaria citri, Rhizoctonia solani , Botrytis cinerea, Botrytis squamosal. 


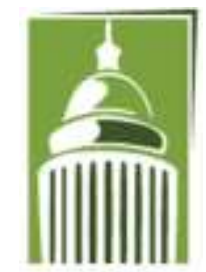

AR F
Global Proceedings Repository

American Research Foundation

ISSN 2476-017X

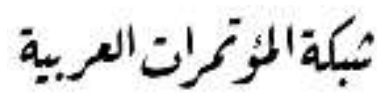

http://arab.kmshare.net/

Available online at http://proceedings.sriweb.org

as of (19) examples of tomato collected as of different dividends isolated (41) species of fungi moneymaking to 22 genera . The greatest communal fungi that F. moniliforme, F. solani, A. alternata A. flavus

\section{4-2Pathogenicity of isolated fungi}

Pathogenicity of 15 species accredited for 9 Genes were documented. 8 species of fungi were affirmative, effectively capable to contaminate plant leaves looking pollution indications of leaf plug. A. citri A. alternata, A.tenuissima , B. cinerea,B.squamosa were extremely infectious and shaped the disease symptoms on extra $75 \%$ from diseased leaves. (M. tassiana) was reasonable capability towards contaminate vegetal leaves , cut protection (50 - 75)\% of diseased leaves. R.solani, C. lunata , F. moniliforme, F. solani and C. sphaerspermum showed fewer infectious . Its grazes were experiential on fewer from $(50) \%$ of diseased leaves, although residual fungi had undesirable pathogenicity consequence and powerless to contaminate leaves of tomato deteriorating to yield every leaf spot indications on immunized leaves. These fungi include D. papendorfii, F. oxysporum, C.cladosporioides S. chartarum ,Table (1).

\section{Table (1):- Pathogenicity of fungi}

\begin{tabular}{|l|l|l|}
\hline Ser. & Fungal isolates & Pathogenicity \\
\hline $\mathbf{1}$ & A. alternata & $\mathbf{7 5 \%}$ \\
\hline $\mathbf{2}$ & A.tenuissima & $\mathbf{7 5 \%}$ \\
\hline $\mathbf{3}$ & A. citri & $\mathbf{7 5 \%}$ \\
\hline $\mathbf{4}$ & B. squamosa & $\mathbf{7 5 \%}$ \\
\hline $\mathbf{5}$ & B. cinerea & $\mathbf{7 5 \%}$ \\
\hline $\mathbf{6}$ & M. tassiana & $\mathbf{5 0 \%}$ \\
\hline $\mathbf{7}$ & F. solani & $\mathbf{2 5 \%}$ \\
\hline $\mathbf{8}$ & F. moniliforme & $\mathbf{2 5 \%}$ \\
\hline $\mathbf{9}$ & R. solani & $\mathbf{2 5 \%}$ \\
\hline $\mathbf{1 0}$ & C. lunata & $\mathbf{2 5 \%}$ \\
\hline 11 & C. sphaerspermum & $\mathbf{2 5 \%}$ \\
\hline 12 & F. oxysporum & $\mathbf{0 . 0 \%}$ \\
\hline 13 & S. chartarum & $\mathbf{0 . 0 \%}$ \\
\hline & & \\
\hline
\end{tabular}




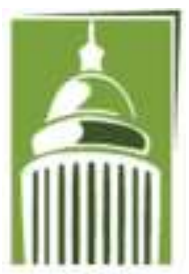

ARF
Global Proceedings Repository

American Research Foundation

ISSN 2476-017X

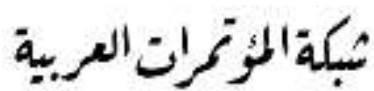

http://arab.kmshare.net/

Available online at http://proceedings.sriweb.org

\begin{tabular}{|l|l|l|}
\hline 14 & D. papendorfii & $\mathbf{0 . 0 \%}$ \\
\hline 15 & C. cladosporioides & $\mathbf{0 . 0 \%}$ \\
\hline
\end{tabular}

The fungal Alternaria is dishonest pathogenic element, particulars contagions to several fruits and vegetable (22). Over previous insufficient centuries plant diseases chic nearly every year, fundamentally payable for soil borne existence of fungi, (2). Alternaria, decorous in place of passive assailant rather than principal pathogen ,(23) detailed this, A. tenuissima that chief (leaf spot) significant pathogen. In the (eggplant), Alternaria testified by way of insignificant, sphere-shaped, chocolate necrotic spots altogether over plant (24). (25) originate Alternaria distant after tomato performance indications in leaf spot infection cultivated below glasshouse environments.

\section{4-3Result of fungal contagion on photosynthetic pigments}

Photosynthesis degrees of are exceptional of greatest important symbols on functional evaluation in plants that associated with chlorophyll content. Consequences protest infected plant by A. citri, chlorophyll a , b tremendously communicable presented uppermost threateningly condensed by $(1.16),(0.18)(\mathrm{mg} / \mathrm{g}$ fresh leaves ) correspondingly compared with (2) , ( 1.50) (mg/g fresh leaves ) in controller plants. A.alternate also protest animated abridged for (chlorophyll a and b) were $(1.89),(0.98)(\mathrm{mg} / \mathrm{g}$ fresh leaves )correspondingly, established fungi not protest evocatively abridged to (chlorophyll a, b) . Chlorophyll reduction from plant leaves for the reason that Alternaria infection can be a position of fungal importance on statement of overjoyed toxins important to deliverance of subtle oxygen sp. instigating instinctive cell death (26).

Table(2) : Influence of fungal contagion on (chlorophyll a and b) in leaves

\begin{tabular}{|l|l|l|}
\hline Managements & $\begin{array}{l}\text { Chl.a (mg/g fresh } \\
\text { leaves })\end{array}$ & $\begin{array}{l}\text { Chl.b (mg/g fresh } \\
\text { leaves) }\end{array}$ \\
\hline Controller & 2 & 1.50 \\
\hline
\end{tabular}




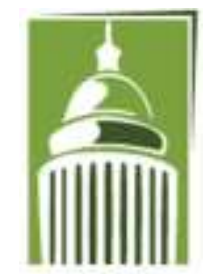

ARF
Global Proceedings Repository

American Research Foundation

ISSN 2476-017X

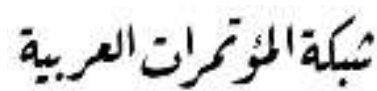

http://arab.kmshare.net/

Available online at http://proceedings.sriweb.org

\begin{tabular}{|l|l|l|}
\hline A. citri & 1.16 & 0.18 \\
\hline A. alternata & 1.89 & 0.98 \\
\hline A.tenuissima & 1.56 & 0.85 \\
\hline M. tassiana & 1.90 & 0.88 \\
\hline B. squamosa & 1.87 & 0.83 \\
\hline B. cinerea & 1.86 & 0.92 \\
\hline
\end{tabular}

(27) originate that in ( broad bean ) Chl.a , Chl. b besides the Carotenoids in leaves evocatively reduced owing for contagion of A.alternata that was highly transmissible presented uppermost evocatively inhibitive importance on formation of photosynthetic pigments likened with control plant. (3) specified that diseased tomato seedlings by A.solani obtainable tremendously significant discount in contents of Chl.a, Chl. b besides the Carotenoids associated with controller.

\section{4-4pectinase activity}

(6) fungal species that divided intended for capabilities for harvest the enzyme bythe methods of cup-plate technique. Totally experienced fungi were pectinase originators then with adaptable degrees. (3) fungi presented great pectinase activity include (A. citri, A.tenuissima, A. alternaria) (28, $25,24) \mathrm{mm}$ correspondingly, additional fungi that create for remain sensible pectinase activity include ( $M$. tassiana, B.squamosal, B. cinerea) were $(18,15$, 14) respectively Boccas et al., (1994) create that, from (248) isolates of fungi enhanced as of chocolate plant besides earth examples divided to the ability for create enzyme, 119 isolate gifted for products pectinase . (28) create that from (5) fungal isolates experienced intended for capability to creating pectinase , many species of A. oryzae besides A. niger show highest manufacturers. (29) found that from( 39) isolates of fungi confirmed for dimensions of creating pectinase in media, single strain individual connected to E. nidulans made this enzyme.

4-5 Influence of changed incubation times on enzyme action produced from A. citri 


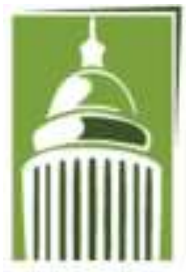

ARF
Global Proceedings Repository

American Research Foundation

ISSN 2476-017X

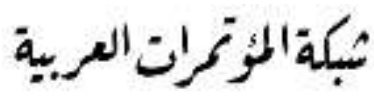

http://arab.kmshare.net/

Available online at http://proceedings.sriweb.org

Pectinase formed from ( A. citri ) was increased with growing of incubation times performance its all-out after (10) days of incubation, afterward (14) days Pectinase activity was concentrated (Table 3 ).

Table(3): Effect of incubation times on pectinase activity

\begin{tabular}{|l|l|}
\hline incubation times( days) & pectinase activity \\
\hline 5 & 1.6 \\
\hline 7 & 2.1 \\
\hline 10 & 3.1 \\
\hline 14 & 2.9 \\
\hline
\end{tabular}

(30) labeled that, extreme products of pectinase through A. phoenicis and A. flavus were increased in 6 days, granting now A. wentii and A. niger were in 8 days from growth. (31) create that, extreme the enzyme action in A.niger recognized afterward 7 days of growth.

4-6 Influence from changed temperature going on enzyme action formed from A. citri

Full enzyme formed from A. citri reached in $30^{\circ} \mathrm{C}$. Considerable amounts from pectinase remained as well increased in $\left(20^{\circ} \mathrm{C}, 25^{\circ} \mathrm{C}, 35^{\circ} \mathrm{C}\right)$ nonetheless this amounts remained usually shortened. Lowest enzyme action reported in( 35) ${ }^{\circ} \mathrm{C}$ (Table 4).

Table(4): Effect of Temperature on pectinase activity

\begin{tabular}{|l|l|}
\hline Temperature $\left({ }^{\circ} \mathrm{C}\right)$ & pectinase activity \\
\hline 20 & 0.7 \\
\hline 25 & 1.9 \\
\hline 30 & 2.8 \\
\hline 35 & 1.5 \\
\hline
\end{tabular}

These consequences analogous to results extended by $(32,33,34)$. They labeled that, optimal pectinase activity from the fungi include $A$. japonicus, $A$. 


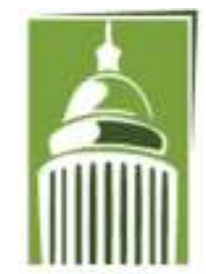

AR F
Global Proceedings Repository

American Research Foundation

ISSN 2476-017X

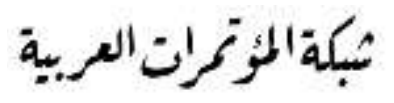

http://arab.kmshare.net/

Available online at http://proceedings.sriweb.org

niger ,A. giganteus was at $(30)^{\circ} \mathrm{C}$. (35) labeled that finest temperature to pectinase manufacture from ( A. falvus ) was at $\left(35^{\circ} \mathrm{C}\right)$. (36) empirical that pectinase manufacture from (P. chrysogenum) was progressive at $\left(35^{\circ} \mathrm{C}\right)$.

4-7Influence of changed $\mathrm{pH}$ values going on enzyme action created from A. citri

Full amount of enzyme might be synthetic once culture medium of (A. citri )initially familiar toward $\mathrm{pH}=6$. Substantial quantities of pectinase also reported in $\mathrm{pH}=2,4,8$, while little amounts of pectinase were experimental in cultures using extra acidity or alkalinity (Table 5).

Table(5): Influence of pH standards in enzyme action

\begin{tabular}{|l|l|}
\hline pH values & pectinase activity \\
\hline 2 & 0.3 \\
\hline 4 & 1.7 \\
\hline 6 & 3.1 \\
\hline 8 & 1.4 \\
\hline
\end{tabular}

(30) found that the greatest $\mathrm{pH}$ for pectinase formation by (A.flavus, A. niger, A. phoenicis , A. wentii ) were ( $8,7,5,7)$ correspondingly. (37) found that extreme pectinase activity by (A. fumigatus) become at ( $\mathrm{pH} 4.0)$. (38)originate that polygalacturonase showed highest pectinase action in $\mathrm{pH}$ $=5$. Furthermore, $\mathrm{pH}=6.5$ was highest appropriate to pectinase formation from ( P. chrysogenum), (39).

\section{4-8 Influence of changed Carbon foundations going on enzyme activity produced from ( A. citri)}

Among four sources of carbon united definitely in culture medium to pectinase manufacture, pectin created resolute pectinase creation from (A. citri ). Substantial quantities from pectinase talented fashionable attendance CMC, maltose by way of carbon sources, whereas glucose was least inducible source for carbon to pectinase creation (Table 6 ). 


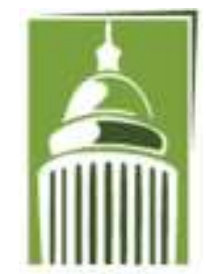

ARF
Global Proceedings Repository

American Research Foundation

ISSN 2476-017X

Available online at http://proceedings.sriweb.org

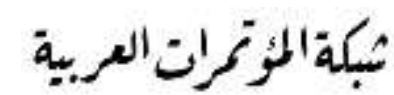

http://arab.kmshare.net/

Table(6): Effect of carbon sources on pectinase activity

\begin{tabular}{|l|l|}
\hline carbon sources & pectinase activity \\
\hline pectin & 3.3 \\
\hline CMC & 2.1 \\
\hline glucose & 0.5 \\
\hline maltose & 2.6 \\
\hline
\end{tabular}

(33) labeled that, extreme formation of polygalacturonase was highest by using pectin as carbon source. (32) untried that highest formation of polygalacturnase (A. niger) was reached by apple fleshy tissue and apple pectin as carbon source.

4-9 Influence of changed nitrogen sources going on enzyme action formed from ( A. citri)

Full produces of pectinase formed from A. citri concluded fashionable incidence of peptone by way of foundation for nitrogen followed via sodium nitrite . Considerable amounts from this enzyme that likewise industrial fashionable presence of ammonium nitrate as source for nitrogen. Potassium nitrate was fewer nitrogen sources talented for the pectinase manufacture, (Table 7).

Table(7): Effect of nitrogen sources on pectinase activity

\begin{tabular}{|l|l|}
\hline nitrogen sources & pectinase activity(U/mL) \\
\hline ammonium nitrate & 1.1 \\
\hline Potassium nitrate & 0.6 \\
\hline Sodium nitrite & 2.8 \\
\hline peptone & 3.1 \\
\hline
\end{tabular}

(40) labeled that pectinase manufacture from $P$. chrysogenum industrialized by ammonium sulphate trailed in ammonium sulphate by way of nitrogen foundation. (41)originate that pectinase action larger in incidence of 


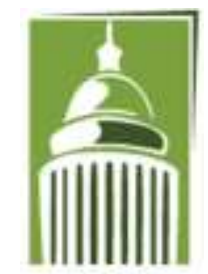

ARF

\section{Global Proceedings Repository}

American Research Foundation

ISSN 2476-017X

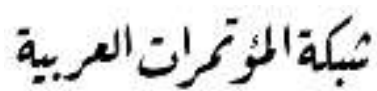

http://arab.kmshare.net/

Available online at http://proceedings.sriweb.org

nitrogen foundations like ammonium sulphate $65 \mathrm{U} / \mathrm{mL}$, peptone displays $37.5 \mathrm{U} / \mathrm{mL}$ then years extract showed $31.6 \mathrm{U} / \mathrm{mL}$.

\section{References:-}

1- Abd-El Kareem, F., N.S. El-Mougy, N.G. El-Gamal and Y.O. Fatouh, (2006). Use of chitin and chitisan against tomato root rot disease under greenhouse conditions. Res. J. Agric. Biol. Sci., 2: 147-152 .

2-Khan, M.A., Abdul Rashid and Iqbal, M.(2003). Evaluation of Foliar Applied Fungicides Against Early Blight of Potato Under Field Conditions. Int. J. Agric. Biol., 5: 543-544 .

3-Faheed, F.A., G.A. Abd-ELaah and A. Mazen, (2005). Alleviation of Disease Effect on Tomato Plants by Heat Shock and Salicylic Acid Infected with Alternaria solani. Int. J. Agric. Biol., 7: 783-789.

4-Fernandez-Acero FJ, Carbu M, Garrido C, Vallejo I, Cantoral JM . (2007 ). Proteomic advances in phytopathogenic fungi. Curr Proteomics 4: 79-88 .

5-Garrido C, Cantoral JM, Carbu M, Gonzalez-Rodriguez EV, Fernandez Acero FJ. (2010) New proteomic approaches to plant pathogenic fungi. Curr Proteomics 7: 306-315.

6-Idnurm A, Howlett BJ. (2001) .Pathogenicity genes of phytopathogenic fungi.Mol. Plant Pathol 2: 241-255.

7-Odds FC, Gow NA, Brown AJP. (2001) .Fungal virulence studies come of age . Genome Biology 2001, 2(3):reviews1009.1-1009.

8-Tivoli B, Baranger A, Avila CM, Banniza S, Barbetti M . (2006). Screening techniques and sources of resistance to foliar diseases caused by major necrotrophic fungi in grain legumes. Euphytica 147: 223-253 .

9-Basu, P. K. (1974). Measuring early blight, its progress and influence on fruit losses in nine tomato cultivars. Can. Plant Dis. Surv. 54:45-51. 


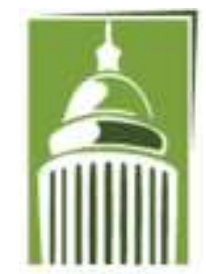

AR F
Global Proceedings Repository

American Research Foundation

ISSN 2476-017X

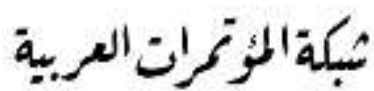

http://arab.kmshare.net/

Available online at http://proceedings.sriweb.org

10-Datar, V. V. and Mayee, C. D. (1981). Assessment of losses in tomato yield due to early blight. Indian Phytopath. 34: 191-195.

11-Mathur, N. and Shekawat, R. (1986). Chemical control of early blight in kharif sown tomato. Indian J. Mycol. Plant Pathol. 16: 235-240.

12-Gwary, D. M. and Nahunnaro, H. (1998). Epiphytotics of early blight of tomatoes in Northeastern Nigeria. Crop Prot. 17: 619-624.

13-Rogers LM, Kim YK, Guo W, Gonzalez-Candelas L, Li D . (2000) .Requirement for either a host or pectin-induced pectate lyase for infection of Pisum sativum by Nectria hematococca. Proc Natl Acad Sci USA 97: 98139818.

14-Ramos AM, Gally M, Garcia MC, Levin L. (2010). Pectinolytic enzyme production by Colletotrichum truncatum, causal agent of soybean anthracnose. Rev Iberoam Micol 27: 186-190.

15-El-Kholl MM, Ragab MM and Hussein MY. (1994) .Alternaria spots of sugar beet in Egypt. Egypt J Phytopathol 22: 179-193 .

16-Abdel-Motaal ,F. (2010). The role of secondary metabolites of the medical solanaceous plant (Hyoscyamus muticus L.) and its associated fungi in plantfungal interactions.

17-Lichtenthaler, H.K., (1987). Chlorophylls and carotenoids: pigments of photosynthetic biomembranes. Meth. Enzymol., 148: 350-382.

18- Hankin L, Zucker LM, Sands DC. (1971). Improved solid medium for the detection and enumeration of pectolytic bacteria. Appl Microbiol 22: 205-209.

19-Lichtenthaler, H.K., (1987). Chlorophylls and carotenoids: pigments of photosynthetic biomembranes. Meth. Enzymol., 148: 350-382 .

20-Sherwood RT. (1966). Pectin lyase and polygalacturonase production by Rhizoctonia solani and other fungi. Phytopathology 56: 279-286. 


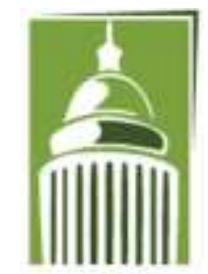

AR F

\section{Global Proceedings Repository}

American Research Foundation

ISSN 2476-017X

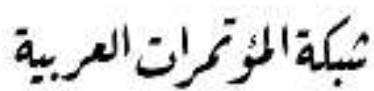

http://arab.kmshare.net/

Available online at http://proceedings.sriweb.org

21-Alkorta I., Llama M.J and Serra J. L.(1994). Interference by pectin in protein determination, Food Sci. Techno., 27, 39-41.

22-Reddy, R., Misra, S.and Chandrashekhariah, R.(2002). Alternaria tenuissima - A new fungal pathogen on mulberry stem. Ind. Phytopathol., 55: $532-533$.

23-Feng, F., Qiu ,D., and Jiang,L.( 2007). Isolation of cDNA sequences encoding the MAP kinase HOG1 and the MAP kinase PBS2 genes of the fungus Alternaria tenuissima through a genetic approach. J. Microbiol. Meth., 69: 188-196.

24-Raja, P., Ramana ,R. and Allam, U.(2005). First report of Alternaria tenuissima causing leaf spot and fruit rot on eggplant (Solanum melongena) in India. New Dis. Rep., 12: 31.

25-Agamy ,R., Alamri1, S., Moustafa,M., and Hashem,M.(2013). Management of Tomato Leaf Spot Caused by Alternaria tenuissima Wiltshire using Salicylic Acid and Agrileen. INTERNATIONAL JOURNAL OF AGRICULTURE \& BIOLOGY,15-2:266-272.

26-Howlett, B.J., (2006). Secondary metabolite toxins and nutrition of plant pathogenic fungi. Curr. Opin. Plant Biol., 9: 371-375.

27- Cole L, Dewey FM, Hawes CR. (1998). Immunocytochemical studies of the infection mechanisms of Botrytis fabae II. Host cell wall breakdown. New Phytol.139:611-622 .

28-Dartora ,A.B., Bertolin TE, Bilibio D, Silveira MM, Costa JA. (2002).Evaluation of filamentous fungi and inducers for the production of endo-polygalacturonase by solid state fermentation. Z. Naturforsch C 57: 666670. 


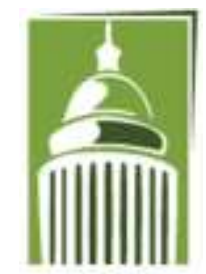

ARF

\section{Global Proceedings Repository}

American Research Foundation

ISSN 2476-017X

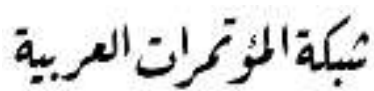

http://arab.kmshare.net/

Available online at http://proceedings.sriweb.org

29-Gouda HAA. (2009) .Studies on xerophilic, acidiphilic and alkaliphilic fungi in Wadi El-Natrun. M SC Thesis, Department of Botany, Faculty of Science, Assiut University.

30-Yadav S, Yadav PK, Yadav KDS. (2007) .Pectin lyases of a few indigenous fungal strains. Journal of Science \& Industrial Research 66: 601604 .

31-Akhter N, Morshed MA, Uddin A, Begum F, Sultan T, et al. (2011). Production of pectinase by Aspergillus niger cultured in solid state media. International Journal of Biosciences 1: 33-42.

32-Mojsov K. (2010) .The effects of different carbon sources on biosynthesis of pectinolytic enzymes by Aspergillus niger. Applied Technologies and Innovations 3: 23-29 .

33-Pedrolli DB, Gomes E, Monti R, Carmona EC .(2008) .Studies on productivity and characterization of polygalacturonase from Aspergillus giganteus submerged culture using citrus pectin and orange waste. Appl Biochem Biotechnol 144:191-200.

34-Palaniyappan M, Vijayagopal V, Viswanathan R, Viruthagiri T. (2009). Screening of natural substrates and optimization of operating variables on the production of pectinase by submerged fermentation using Aspergillus niger MTCC 281 Afri J Biotech 8: 682-686.

35-Osman NFA. (2005) .Ecological and physiological studies on fungi associated with post-harvested rot of some fruits.

36-Banu AR, Devi MK, Gnanaprabhal GR, Pradeep BV, Palaniswamy M .(2010). Production and characterization of pectinase enzyme from Penicillium chrysogenum. Indian J Sci Technol 3: 377-381.

37-Phutela,U., Dhuna, V., Sandhu ,S. and Chadha,B.(2005). PECTINASE AND POLYGALACTURONASE PRODUCTION BY A THERMOPHILIC ASPERGILLUS FUMIGATUS ISOLATED FROM 


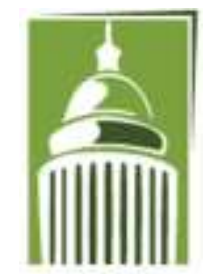

ARF
Global Proceedings Repository

American Research Foundation

ISSN 2476-017X

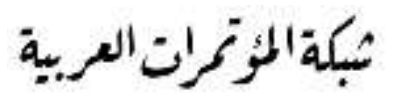

http://arab.kmshare.net/

Available online at http://proceedings.sriweb.org

DECOMPOSTING ORANGE PEELS. Brazilian Journal of Microbiology 36:63-69 .

38-Wang, S., Lian,Z., Wang, L., Yang,Z. and Liu,Y.(2015). Preliminary investigations on a polygalacturonase from Aspergillus fumigatus in Chinese $\mathrm{Pu}$ 'er tea fermentation. Bioresources and Bioprocessing . 2:33.

39-Sandri IG, Lorenzoni CMT, Fontana RC, da Silveira MM. (2013) .Use of pectinases produced by a new strain of Aspergillus niger for the enzymatic treatment of apple and blueberry juice. LWT-Food Sci Technol 51(2):469475 .

40-Lobato AKS, Gonçalves-Vidigal MC, Vidigal Filho PS, Andrade CAB, Kvitschal MV, et al. (2010). Relationships between leaf pigments and photosynthesis in common bean plants infected by anthracnose. N Z J Crop Hortic Sci 38: 29-37.

41-Tariq, A and Reyaz, A.(2012). The influence of carbon and nitrogen sources on pectinase productivity of Penicillium chrysogenum in solid state fermentation. International Research Journal of Microbiology. 3(5) 202-207. 